\title{
Durability Behaviour of Geopolymer Concrete with Metakaolin and GGBS
}

\author{
Ganesan Nagalingam, Ramesh Babu Chokkalingam, Meyyappan PL
}

\begin{abstract}
This study consists of preparation of Geopolymer concrete mix with Ground Granulated Blast furnace Slag (GGBS) which is followed by the usage of Metakaolin in replacement of GGBS with $5 \%$ variation from 0 to $25 \%$. From previous researches on geopolymer concrete with GGBS, an optimized mix is selected and tested for durability behaviour. A 12 Molarity sodium hydroxide solution along with sodium silicate in the ratio of 1:2.5 is used as activator in this study. La Hypercrete S25 which belongs to the category of carboxylic is used as admixture for escalating the workability. Water absorption, Acid resistance, and Rapid Chloride Penetration (RCPT) are the durability tests performed on the specimens. The prepared specimens are water cured at room temperature for the required days in accordance with the codal guidelines and tested for durability. For water absorption test, concrete cylinders of $50 \mathrm{~mm}$ dia and $100 \mathrm{~mm}$ height are prepared. $100 \mathrm{~mm}$ size cube specimens prepared for acid resistance test. The specimens for RCPT include preparation of discs of $100 \mathrm{~mm}$ dia and $50 \mathrm{~mm}$ height. In all the test specimens, GGBS is replaced by Metakaolin. It is believed from the test results that geopolymer concrete with Metakaolin and GGBS performs well in durability aspects.
\end{abstract}

Keywords : activator, admixture, Geopolymer concrete, GGBS, Metakaolin,

\section{INTRODUCTION}

To minimize the depletion of natural resources, many researchers started using the industrial waste materials as construction material either an additive or partial replacement of the conventional material and achieved with good solutions. The main cause of atmospheric pollution is the emission of green house gases during the cement manufacture. This pollution can be minimized only by restricting the manufacture and usage of cement. Geopolymer concrete is one which completely eliminates the usage of cement. Many research works has proved that geopolymer concrete has excellent mechanical and durability properties. $[1,2]$ Poly condensation in silica and alumina is responsible for the strength development of geopolymer concrete.[3] When Sodium Hydroxide and Sodium Silicate mixture is used as an activator, the thermal activation takes place and gives strength the concrete[4,5]. Similarly, Metakaolin has high

Revised Manuscript Received on December 30, 2019.

* Correspondence Author

*Ganesan Nagalingam, Department of Civil Engineering, Kalasalingam Academy of Research and Education, Krishnankoil, Virudhunagar District, Tamilnadu .Email: civilganesan139@gmail.com

Ramesh Babu Chockkalingam, Department of Civil Engineering, Kalasalingam Academy of Research and Education Krishnankoil, Virudhunagar District, Tamilnadu . Email: babussr@gmail.com

Meyyappan PL, Department of Civil Engineering, Kalasalingam Academy of Research and Education ,Krishnankoil, Virudhunagar District, Tamilnadu . Email: meyyappan@klu.ac.in reactivity with alkali solutions [6], in this work, steps have been taken to use both Metakaolin and GGBS in geopolymer concrete for the response of durability behaviour. Experiments prove that the rate of absorption of geopolymer is less. $[10,11,12]$

\section{MATERIALS}

\section{A. Ground Granulated Blast furnace Slag(GGBS)}

Ground Granulated Blast furnace Slag (GGBS) is collected from the blast furnace in iron manufacturing industries. From the physical properties, it is found that the specific gravity of GGBS used in this study is about 2.8. XRD analysis was performed on GGBS to determine its oxide composition and the details are presented in Fig 1.

\section{B. Metakaolin}

Metakaolin is a pozzolanic material and it is obtained by calcinations of Algerian kaolin at $700^{\circ} \mathrm{C}$ for 7 hours. The silica and alumina content of Metakaolin reacts with free lime and forms C-S-H gel and alumina silicates which are responsible for the strength improvement. Metakaolin is a white coloured fine particle. The specific gravity of Metakaolin used in this study is 2.7 .

\section{Fine aggregate}

The fine aggregate used in this study belongs to Zone 2 -IS 382- 2016. The sand which passes through $2.36 \mathrm{~mm}$ sieve is used in this work. The fine aggregate has the specific gravity of 2.80 with fineness modulus 3.28[7]

\section{Coarse aggregate}

The coarse aggregate used in this study satisfies the guidelines of IS 383- 1970. The crushed granite stone aggregate which passes through $4.75 \mathrm{~mm}$ sieve is used in this work. The coarse aggregate has the specific gravity of 2.808 with fineness modulus 7.05 .

\section{E. Activator}

A 12 Molarity Sodium Hydroxide solution and sodium silicate mixed in the ratio of $1: 2.5$, prepared 24 hours before casting the specimens is used as activator.

\section{F. Admixture}

La-Hypercrete - S25 (HTS code 38244090), a modified carboxylic based ether is used in this study to increase the workability of geopolymer concrete. [8] 


\section{Durability Behaviour of Geopolymer Concrete with Metakaolin and GGBS}

\section{G. Mix proportion for the experimental work}

The proportions of materials used in this experimental work is tabulated in Table I below.[9]

Table- I: Materials for the experimental work

\begin{tabular}{|c|c|c|c|c|c|c|}
\hline Materials & $\begin{array}{c}\text { GG } \\
\text { BS }\end{array}$ & FA & CA & $\begin{array}{c}\mathbf{N a} \\
\mathbf{O H}\end{array}$ & $\begin{array}{c}\mathbf{N a}_{2} \\
\mathbf{S i O}_{3}\end{array}$ & $\begin{array}{c}\text { Ad-mixt } \\
\text { ure }\end{array}$ \\
\hline $\begin{array}{c}\text { Quantity } \\
\left(\mathrm{kg} / \mathrm{m}^{3}\right)\end{array}$ & 550 & 689.10 & 1113.2 & 55 & 137.5 & 5.5 \\
\hline
\end{tabular}
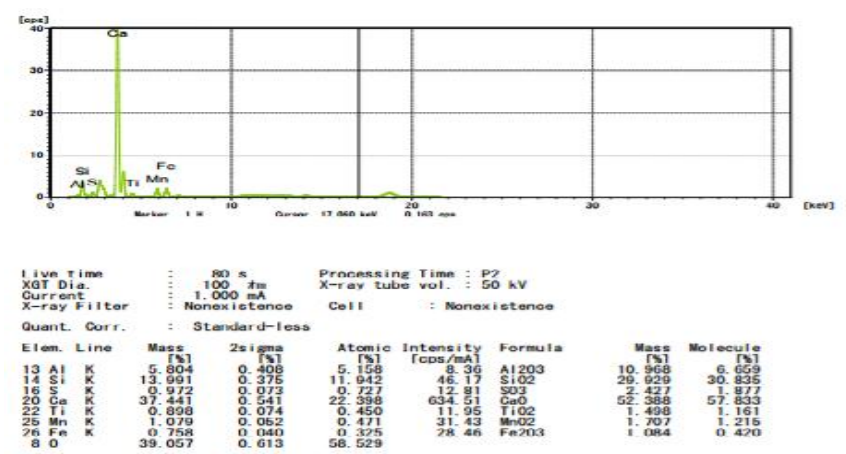

Fig.1. XRF Analysis of GGBS

III. EXPERIMENTAL WORK

A. Metakaolin and GGBS quantities for Mixes
The Metakaolin and GGBS quantities used in various mix combinations are tabulated in Table II below.

Table- II: Metakaolin and GGBS quantities

\begin{tabular}{|c|c|c|c|c|c|c|}
\hline Mix ID & S1 & S2 & S3 & S4 & S5 & S6 \\
\hline $\begin{array}{c}\text { Metakaolin } \\
\text { (\%) }\end{array}$ & 0 & 5 & 10 & 15 & 20 & 25 \\
\hline GGBS (\%) & 100 & 95 & 90 & 85 & 80 & 75 \\
\hline
\end{tabular}

\section{B. Water absorption test and test results:}

Cylinders of $50 \mathrm{~mm}$ diameter and $100 \mathrm{~mm}$ height are prepared for water absorption test. Specimens are cast for each mix ID mentioned in Table 2 . The specimens are cured for 28 days and kept in oven at $110^{\circ} \mathrm{C}$ for 24 hours. This dry weight is $\mathrm{W} 1$. Then the specimens are kept inside the warm water at $90^{\circ} \mathrm{C}$ for $3 \frac{1}{2}$ hours. The wet weight is taken as $\mathrm{W} 2$. The percentage of water absorption is determined by [(W2-W1)/W1] x 100. The water absorption test results are tabulated in Table III.

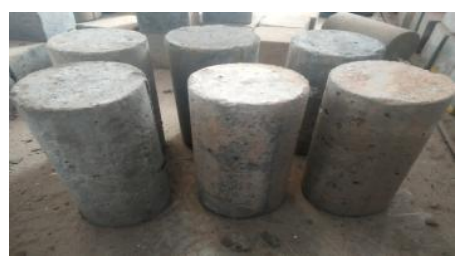

Fig.2.Specimens for water absorption test

Table- III: Water absorption test results

\begin{tabular}{|c|c|c|c|}
\hline $\begin{array}{c}\text { Specimen } \\
\text { ID }\end{array}$ & Dry weight of specimens in gms (W1) & Wet weight of specimens in gms (W2) & Water \\
\hline S1 & 572 & 586 & 2.45 \\
\hline S2 & 580 & 593 & 2.24 \\
\hline S3 & 610 & 623 & 2.13 \\
\hline S4 & 608 & 620 & 1.97 \\
\hline S5 & 612 & 624 & 1.96 \\
\hline S6 & 625 & 614 & 1.79 \\
\hline
\end{tabular}

\section{Rapid Chloride Penetration test and test results:}

To calculate this Chloride penetration, two discs of $100 \mathrm{~mm}$ dia with $50 \mathrm{~mm}$ height are cast for each mix ID and cured for 28 days and tested as per ASTM C 1202 (2017) standards. The concrete disc is sealed in between the two-glass container and the space between the disc and the glass containers are sealed using the sealant. The cathode terminal has $3 \%$ sodium chloride solution and the anode terminal has $0.3 \mathrm{M}$ sodium hydroxide solution. The wires of the voltage box and glass containers are connected. Now the RCPT setup is complete. Set the voltage of 60 Volts in the DC power supply. The initial reading is taken after the voltage setup. The solution is passed through the disc and gave the value of rate of transported chloride ions. Readings are noted for every 30minutes continuously and the log time is set as 6hrs. 60 Volts current is charged continuously till this log time gets over. The chloride permeability is calculated by $2 \times 900 \times$ Cumulative coulombs. Where, Cumulative coulombs $=$ I $0+$ I $30+$ I $60+$ I 90 + I 120 + I 150 + I 180 + I 210 + I $240+$ I 270 + I $300+$ I $330+$ I 360. From this experimental work, it is concluded that since chloride ion permeability values falls between $2000-$ 4000 coulombs, it is under Moderate range of acceptability. The experimental set up is shown if Fig_ 3. The test results are shown in Fig.4 and the average RCPT test results are shown in Table IV . 
Table- IV: RCPT test results

\begin{tabular}{|c|c|c|c|c|c|c|c|}
\hline Mix ID & S1 & $\mathbf{S 2}$ & $\mathbf{S 3}$ & S4 & S5 & S6 & Remarks \\
\hline $\begin{array}{c}\text { Charge passed } \\
\text { (Coulombs) }\end{array}$ & 3189.6 & 3137.4 & 3139.2 & 3047.4 & 2802.6 & 3004.2 & \multirow{2}{*}{$\begin{array}{l}\text { As per ASTM C 1202- } 2017 \\
\text { ratings, the values lies in } \\
\text { between 2000-4000 which } \\
\text { indicates the Chloride ion } \\
\text { permeability is Moderate. }\end{array}$} \\
\hline Chloride permeability & Moderate & Moderate & Moderate & Moderate & Moderate & Moderate & \\
\hline
\end{tabular}

\section{Acid resistance test (Sulphate Attack) and test} results:

In this test, concrete cubes of $100 \mathrm{~mm}$ size are cast[9]. The cube specimens are immersed in $1 \%$ sulphuric acid for 28 days. Six cubes are cast for each mix ID in which 3 cubes are

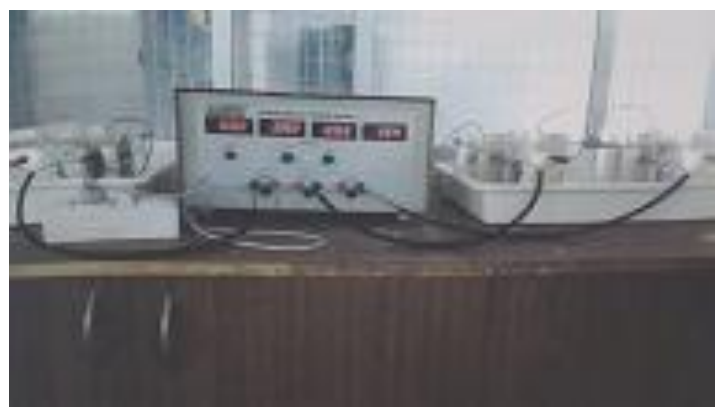

Fig.3.RCPT test set up subjected to water curing and 3 cubes are subjected to acid curing. The specimens are tested after 28 days as per the codal provisions of IS: 516-1959. The cube specimens are shown in Fig 4 and the acid resistance test results are tabulated in Table $\mathrm{V}$.

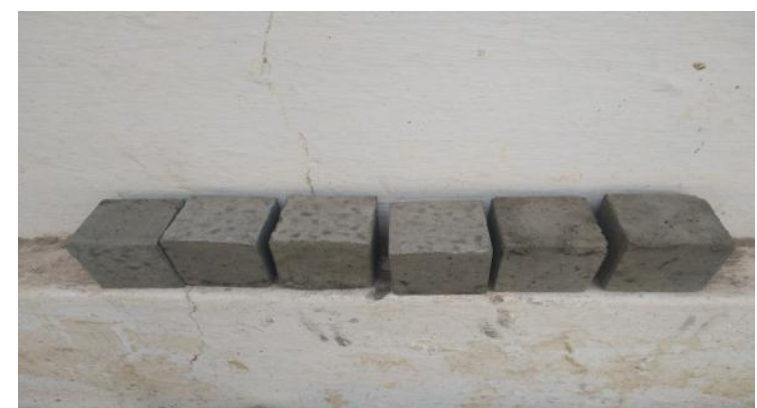

Fig.4. Cube specimens for acid resistance test

Table- V: Average compressive strength results of acid resistance test

\begin{tabular}{|c|c|c|c|}
\hline Mix ID & $\begin{array}{c}\text { 28 days Average compressive } \\
\text { strength of water curing } \\
\left(\mathbf{N} / \mathbf{m m}^{\mathbf{2}}\right)\end{array}$ & $\begin{array}{c}\text { 28 days Average compressive } \\
\text { strength of acid curing } \\
\left(\mathbf{N} / \mathbf{m m}^{\mathbf{2}}\right)\end{array}$ & \% Reduction \\
\hline S1 & 38.22 & 32.46 & 15.07 \\
\hline S2 & 40.61 & 34.85 & 14.18 \\
\hline S3 & 42.90 & 37.14 & 13.42 \\
\hline S4 & 44.21 & 38.45 & 12.43 \\
\hline S5 & 46.33 & 40.57 & 14.25 \\
\hline
\end{tabular}

\section{ACID RESISTANCE TEST RESULTS}

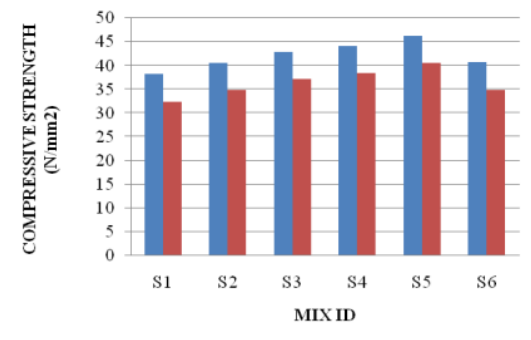

COMPRESSIVE STRENGTH AT AMBIENT CURING - COMPRESSIVESTRENGTH AT ACID CURING

Fig.5. Acid resistance test results

\section{DISCUSSION ON TEST RESULTS}

\section{A. Water absorption test:}

The water absorption for $\mathrm{S} 1$ specimen (0\% Metakaolin and $100 \%$ GGBS) is $2.45 \%$. When the GGBS is replaced by Metakaolin gradually, the water absorption also decreases and reached the value of $1.79 \%$ for S6 specimens. (25\%
Metakaolin and 75\% GGBS). From the test results, it has been concluded that the water absorption decreases with increase in Metakaolin quantity.

\section{B. Rapid Chloride Penetration test:}

The RCPT test result of all the mix specimens gives MODERATE result. It shows that the geopolymer concrete with Metakaolin and GGBS performs uniformly for all replacements.

\section{Acid resistance rest:}

The 28 days average compressive strength value of S1 specimens is $38.22 \mathrm{~N} / \mathrm{mm}^{2}$ for ordinary curing and it is 32.46 $\mathrm{N} / \mathrm{mm}^{2}$ for acid curing. This value is approximately $84 \%$ value of the ordinary water cured specimens. When the GGBS is gradually reduced by the addition of Metakaolin in 5 to $25 \%$, with a variation of $5 \%$, the compressive strength value also increases from the value of S1 specimens. 


\section{Durability Behaviour of Geopolymer Concrete with Metakaolin and GGBS}

All the acid treated specimens are having nearly $80 \%$ of the compressive strength value of ordinary water cured specimens.

\section{CONCLUSIONS}

The conclusions based on the limited observations from the present investigation on properties of Metakaolin and GGBS based Geopolymer concrete is as follows.

(i) The water absorption value decreases for increased quantity of Metakaolin in the GGBS based geopolymer concrete.

(ii) Geopolymer concrete with GGBS performs uniformly with MODERATE chloride permeability for all the replacement ratios of GGBS by Metakaolin from 5 to $25 \%$ with a variation of $5 \%$.

(iii) The acid treated geopolymer concrete specimens gives nearly $80 \%$ compressive strength of the normal water cured specimens.

\section{REFERENCES}

1.B.Singh, G.Ishwarya, Gupta M.Bhattacharyya "Geopolymer concrete: A review of some recent developments" Construction and Building Materials , 2015, pp 78-90

2.Daniel L.Y. Kong, Jay G. Sanjayan "Effect of elevated temperatures on geopolymer paste, mortar and concrete" Cement and Concrete Research, 2010, pp 334-339

3.J Davidovits, "Geopolymer chemistry and application,"2nd edition, Saint-Quentin(France);Institute Geopolymer; 2008.

4.Ramesh Babu Chockalingam, N Ganesan, "A Study on the Strength Development of Geopolymer concrete using Fly ash" International Journal of Engineering and Technology, 2017, pp 163-167

5. P Chindaprasirt, W Chalee," Effect of sodium hydroxide concentration on chloride penetration and steel corrosion of fly ash based geopolymer concrete under marine site" Construction and Building Materials 2014, pp 303- 310

6.B Sarath Chandra Kumar, K Ramesh , P Poluraju "An Experimental investigation on flexural behaviour of GGBS and Metakaolin based Geopolymer concrete" ARPN Journal of Engineering and Applied Sciences 12 pp $2052-2062$

7.Indian Standard Code of practice for specification for coarse and fine aggregates from natural sources for concrete, IS: 383 - 1970, Bureau of Indian Standards, New Delhi, India

8.Indian Standard code of practice for specifications for admixtures for concrete IS:9103-1999, Bureau of Indian Standards, New Delhi, India

9.Indian Standard Code for recommended guidelines for concrete mix design IS:10262-2009, Bureau of Indian Standards, New Delhi.

10.Salmabanu Luhar, Urvashi Khandelwal "A Study on Water Absorption and Sorptivity of Geopolymer Concrete" SSRG International Journal of Civil Engineering (SSRG-IJCE),2015,pp 1-9

11.T N JayShankar, P S Nagaraja , "Evaluation of Water Absorption and Sorptivity Properties of FlyAsh, GGBS, M-Sand Based Glass Fiber Reinforced Geopolymer Concrete" International Research Journal of Engineering and Technology (IRJET) 5 pp 1-5

12.Smruthimol Joseph, V Sreevidya, R Anuradha ,R. Venkatasubramani, "Effect of water absorption, acid attack and sulphate attack on durability properties of geopolymer mortar" International Journal of Emerging Trends in Engineering and Development , pp 316-322

\section{AUTHORS PROFILE}

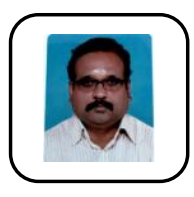

Ganesan Nagalingam completed his UG in Civil Engg. from A.C.Tech, Karaikudi and PG in Structural Engineering from Annamalai University, and pursuing his PhD from Kalasalingam Academy of Research and Education. He has more than twenty five years of experience in teaching and industry. His areas of research include geopolymer concrete, high performance concrete etc.

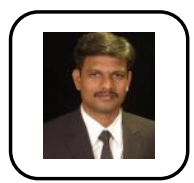

Ramesh Babu Chokkalingam completed his $\mathrm{Ph} . \mathrm{D}$. from IIT Chennai. He has more than ten years of experience in teaching and research. His areas of research includes pervious concrete, geopolymer concrete, and high volume flyash concrete.

Dr. PL. Meyyappan has completed his graduation and post-graduation from Bharathiyar University and Karunya University respectively. He completed his $\mathrm{PhD}$ from Kalasalingam University. He has 13 years of teaching experience. He has completed 2 sponsored research projects from

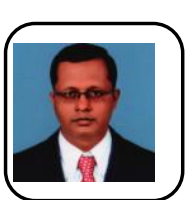
TNSCST and published more than 25 papers in peer reviewed journals and conferences. He is a life member in ISTE, IEI, IGS, ISET, ISRS. He is serving as Editorial Board Member and Reviewer in various reputed Journals. 